15. Schweitzer Named to Direct Work at Sosua; Troncoso Decorates Six. Jewish Telegraphic Agency. Daily News Bulletin. 1941. February, 4. Vol. VIII. № 48. P. 3.

16. Text of the Dominican refugee offer. 1939. October, 19. Dominican Project. 19391941. Myron C. Taylor Papers. Archivists of the Franklin D. Roosevelt Library and Museum

17. The Nazi Holocaust. Historical articles on the destruction of European Jews. Volume 1. Part 8. Bystanders to the Holocaust / ed. by Michael Robert Marrus. London, Westport: Meckler, 1989. 474 p.

18. Turits R. L. A World destroyed, a nation imposed: the 1937 Haitian Massacre in the Dominican republic. Hispanic American Historical Review. 2002. Volume 82. Issue 3. Pp. 589-635.

19. Virgin Islands Refugee Plan Revived in Washington. Jewish Telegraphic Agency. Daily News Bulletin. 1941. March, 21. Vol. VIII. № 86. P. 2.

20. Wells A. Tropical Zion: General Trujillo, FDR, and the Jews of Sosúa. Durham, London: Duke University Press, 2009. 480 p.

21. Wischnitzer M. The Historical Background of the Settlement of Jewish Refugees in Santo Domingo. Jewish Social Studies. 1942. Vol. 4. № 1. Pp. 45-58.

22. Wyman D. S., Rosenberg C. H. The World Reacts to the Holocaust. Baltimore: The Johns Hopkins University Press, 1996. 981 p.

УДК 94:3391.924 (536)

\title{
ОСОБЛИВОСТІ РОЗВИТКУ ІНТЕГРАЦІЙНИХ ПРОЦЕСІВ У РЕГІОНІ ЗАТОКИ ПІСЛЯ РЕВОЛЮЦІЙ «АРАБСЬКОЇ ВЕСНИ»: ВИСНОВКИ ДЛЯ УКРАЇНИ
}

\section{Швед В'ячеслав}

Проаналізовано історичні витоки формування сучасної інтеграчійної архітектури у такому ключовому регіоні Близького Сходу, як Затока, визначено головні тендениії та особливості розвитку інтеграиійних прочесів у зазначеному просторі після революиій «арабської весни». Виявлено основні чинники підвищення ролі аравійських монархій в арабському світі протягом зазначеного часу.

Досліджено вплив на ускладнення прочесів інтеграції у рамках такого об'єднання, як Рада співробітництва арабських держав Затоки (РСАДЗ); таких чинників, як політичне загострення саудівсько-іранського протистояння, близькосхідна політика нового президента США Д. Трампа, катарська криза тощо.

Розглядаються останні спроби Саудівської Аравї спільно з Об'єднаними Арабськими Еміратами сформувати новий иентр інтеграційного тяжіння лояльних до них арабських держав, насамперед Сгипту та Йорданії через такі проекти, як новий воєнно-політичний та економічний союз між Саудівською Аравією та ОАЕ, а також проект NEOM. 
Сформульовано основні висновки щуодо врахування нинішнього стану інтеграційних процесів та геополітичного балансу в регіоні Затоки на реалізацію стратегічних завдань Украйни на Близькому Сході в цілому і у регіоні Затоки зокрема.

Ключові слова: інтеграчійні прочеси, Близький Схід, Затока, Рада співробітництва арабських держав Затоки, катарська криза.

Протягом останнього десятиліття регіон Затоки, який посідає нині головне місце в арабському світі, зазнав кардинальних змін. «Арабська весна», запекла конфронтація аравійських монархій з іранським режимом, прихід до влади нової генерації політиків у Саудівській Аравії та інші чинники призвели до серйозної корекції інтеграційних процесів у зазначеному регіоні, виявили низку нових тенденцій та особливостей.

У цьому контексті важливо здійснити системний аналіз сучасних інтеграційних процесів у зазначеному регіоні арабського світу. Це дозволить опрацювати оптимальний формат стратегічних орієнтирів зовнішньополітичного курсу Української держави з арабськими країнами Затоки, розкрити їхні потенційні можливості як важливих партнерів нашої держави у відстоюванні їі територіальної цілісності, поверненні анексованих та окупованих українських територій та у кардинальній трансформації України.

В Україні аналізові цих процесів присвячені роботи О. А. Коппель, Б. О. Пархонського, М. А. Субха, В. О. Шведа та інших. 3 огляду на важливість аналізу зазначених питань для обгрунтування зовнішньополітичного курсу США у регіоні Затоки, вони активно досліджуються у таких американських аналітичних центрах, як Вашингтонський інститут Близького Сходу, Вашингтонський інститут арабських держав Затоки, Інститут Брукінса та деяких інших.

Незважаючи на пророблену значну роботу у дослідженні запропонованої тематики, існують такі фактично ще невирішені проблеми, особливо у вітчизняній історіографії, як виявлення та аналіз тих чинників, що дозволили арабським монархіям Затоки посісти лідируючі позиції в сучасному арабському світі, роль саудівсько-еміратського альянсу у зміні стратегічного ландшафту Близького Сходу і регіону Затоки, головні чинники сучасної корекції інтеграційних процесів у зазначеному регіоні, формування нових інтеграційних проектів на основі наявної РСАДЗ і таких країн, як Сгипет, Йорданія тощо.

Метою статті є аналіз особливостей сучасних інтеграційних процесів у регіоні Затоки в контексті тих стратегічних завдань, що постали нині перед Українською державою.

Джерельною базою статті стали аналітичні доповіді про розвиток РСАДЗ, виступи та інтерв'ю керівництва провідних арабських країн Затоки, документи та матеріали офіційного та робочого візитів Президента України П. Порошенка до Держави Кувейт і Держави Катар, фактичний матеріал, що міститься у використаних статтях провідних американських, європейських та арабських фахівців із зазначеної проблематики. 
На трансформаційні процеси у Близькосхідному регіоні протягом останнього часу найбільш суттєво вплинули дві події - інтервенція США в Іраку у 2003 р. та події «Арабської весни» 2010-2011рр., які вирішальним чином і визначили спрямованість змін у геополітичному та геостратегічному балансі сил у регіоні. Внаслідок цих двох ключових моментів в історичному розвитку Близькосхідного регіону відбулось достатньо серйозне зниження ролі таких традиційних регіональних центрів сили, як Багдад, Каїр та Дамаск. Вакуум, що утворився, був заповнений аравійськими монархіями Затоки, які виявили енергійність та рішучість. Спираючись на свої колосальні фінансові резерви, відносну внутрішню стабільність та нову динамічну генерацію політиків, вони досить швидко здобули безпрецедентний вплив. Лідерами цієї групи арабських країн Затоки стали Саудівська Аравія та Об'єднані Арабські Емірати, які згодом сформували та запропонували бачення свого власного майбутнього та регіону Затоки в цілому [10].

У 1981 р. шість аравійських монархій створили інтеграційне об'єднання - Раду співробітництва арабських держав Затоки (РСАДЗ), яка впродовж майже чотирьох десятиліть була найуспішнішою регіональною структурою на теренах арабського світу, своєрідним локомотивом його історичного поступу. Виникнення РСАДЗ стало результатом внутрішніх регіональних та міжнародних процесів протягом 70-х-80-х рр. $\mathrm{XX}$ ст., які не лише створили необхідні об'єктивні умови такого інтеграційного об'єднання у просторі Аравійського півострова, але й визначили його головні особливості, ступінь міцності та релейні точки вразливості. Створення такої структури обумовлювалось не лише потребами економічного, соціального та гуманітарного розвитку, а й дуже серйозними безпековими, воєнно-політичними та геополітичними викликами, що постали перед аравійськими монархіями наприкінці 1970-х рр. У 1979 р. в Ірані перемогла антишахська революція, після якої в країні було встановлено необмежений теократичний режим, який під гаслами «ісламської революції» розпочав активну експансіоністську політику в регіоні. Буквально через кілька місяців після перемоги революції 1979 р. в Ірані, розпочалася ірано-іракська війна. Ці дві події відіграли надзвичайно важливу роль у якнайшвидшому створенні інтеграційного об'єднання аравійських монархій, яке швидко почало набирати рис воєнно-політичного об'єднання [7].

Загалом у процесі історичного розвитку РСАДЗ можна виділити 4 етапи: травень 1981 р. - вересень 2001 р.; вересень 2001 р. - початок 2011 р.; початок 2011 р. травень 2017 p. i, нарешті, останній, четвертий, який розпочався 35 червня 2017 р. Протягом першого етапу свого розвитку у Раді була опрацьована та сформована у комплексному вигляді структура регіональної організації, утверджені головні принципи діяльності об'єднання у безпековій, політичній, економічній, фінансовій та гуманітарній сферах. Наступний, другий етап став одним із найуспішніших періодів розвитку РСАДЗ, коли країни-члени Ради досягли серйозних успіхів у розвиткові інтеграційних процесів (укладання економічної угоди у 2001 р., створення спільного ринку РСАДЗ у 2007 р., проголошення створення Монетарного союзу у 2008 р., ухва- 
лення єдиної оборонної стратегії у 2009 р. тощо), а також у сфері здійснення політичних та соціальних реформ кожної з країн-членів Ради на національному рівні $[15,2]$.

Третій етап у розвиткові інтеграційного об'єднання характеризується організацією відсічі «арабській весні» та переходу у контрнаступ проти загрози iï нової хвилі. Протягом зазначеного етапу було здійснено успішний переворот у Єгипті та відсторонено від влади М. Мурсі - ставленика «Братів-мусульман», формується Об'єднана арабська коаліція, яка розпочала військові дії проти проіранських угрупувань хуситів у Смені $[16,111]$. Також характерною прикметою передостаннього етапу розвитку об'єднання стало розгортання «революції зверху» через початок здійснення або оновлення масштабних програм глибоких трансформаційних реформ, що у цілому було своєрідною відповіддю правлячих режимів країн-членів РСАДЗ на «арабську весну».

Лідером цього процесу стала Саудівська Аравія, де нині доволі швидкими темпами відбувається перехід влади до нової генерації дому Саудів - внуків та правнуків засновника саудівської династії. Безперечним лідером цієї групи молодих політиків у Саудівській Аравії, так званих «младосаудитів», став нинішній 33-річний наслідний принц Мохаммед бін Салман. Перехід до розгортання широких трансформаційних зрушень став об'єктивною необхідністю внаслідок дії низки серйозних чинників, пов'язаних передусім із відмовою від рентної моделі економіки та тих складних безпекових викликів, що постали перед Королівством [8].

У Саудівській Аравії та інших аравійських монархій були розроблені та почали втілюватися глибокі реформи, які назвали «Баченням» і які визначали пріоритетні стратегії у строках і напрямах досягнення справжньої диверсифікації, випереджаючого розвитку приватного сектору, досягнення всебічного економічного зростання, впровадження механізмів зменшення залежності від закордонної робочої сили. Султанат Оман першим створив «Бачення Оману 2020» у 1995 р., далі подібне зробили Бахрейн та Катар у 2008 р., Кувейт («Бачення Кувейту 2035») та Об’єднані Арабські Емірати («Бачення ОАЕ 2021») у 2010 р. і наприкінці Саудівська Аравія із їі «Баченням 2030» у 2016 р. Кілька 3 цих документів було оновлено та ухвалено у новому форматі, включаючи Оман і Кувейт [4].

Важливість нинішніх перетворень у Саудівській Аравії полягає у тому, що глибокі трансформаційні процеси відбуваються на основі переосмислення та реформування ісламської ідентичності у напрямі більшої поміркованості та толерантності. У цьому плані дуже показовим та значущим став виступ наслідного принца Саудівської Аравії Мохаммеда бін Салмана на форумі «Ініціатива інвестування майбутнього» та його інтерв'ю британській газеті «The Guardian» від 24.10.2017 р. Одним із головних меседжів зазначеного інтерв'ю став заклик до повернення країни до «поміркованого ісламу» та прохання до глобальної підтримки трансформації вкрай консервативного королівства у відкрите суспільство, яка пояснює роль громадян та заохочує інвесторів [3].

Водночас серйозне ускладнення геополітичної та безпекової ситуації у Близькосхідному регіоні і безпосередньо у районі Затоки обумовило настання останнього, 
четвертого етапу у розвитку РСАДЗ. Головною його характерною рисою стала безпрецедентна катарська криза, що неминуче, незважаючи на всі можливі варіанти ії розв’язання, серйозно позначиться на інтеграційних процесах у регіоні Затоки.

Витоки катарської кризи неможливо зрозуміти без врахування того, що на сьогодні найбільш гострий та непримиренний конфлікт у Близькосхідному регіоні $є$ непримиренне саудівсько-іранське протистояння. Саме логікою розвитку та загострення цього протистояння й обумовлена поява катарської кризи. Двоє нинішніх головних лідерів провідних країн РСАДЗ - Саудівської Аравії та Об'єднаних Арабських Еміратів - наслідний принц Саудівської Аравії Мохаммед бін Салман та наслідний принц Об'єднаних Арабських Еміратів Мохаммед бін Заєд аль Нагаян поставили перед собою за мету трансформувати традиційну архітектуру безпеки Ради співробітництва із захисної на наступальну, і у цьому контексті стали вважати надалі неприпустимим існування достатньо автономної зовнішньої політики Катару та підтримання ним нормальних відносин із Іраном [9]. Імпульсивність, нестриманість обох наслідних принців призвела до відкритого конфлікту із Катаром, коли 5 червня 2017 р. чотири арабські країни - Саудівська Аравія, Єгипет, Об'єднані Арабські Емірати та Бахрейн, які об'єдналися у так званий «антитерористичний квартет», оголосили про повну блокаду Катару.

Також необхідно зазначити, що нинішня катарська криза, яка створила пряму загрозу подальшому існуванню РСАДЗ, має глибоке коріння, яке тягнеться ще $з$ початку 90-х рр. минулого століття. Це пов'язано з домінуючим положенням Саудівської Аравії у Раді співробітництва, особливо у сфері регіональної безпеки. Більшість країн-членів об'єднання чинили спротив спробам Саудівської Аравії у Раді співробітництва, особливо у сферах регіональної безпеки. Більшість країн-членів об'єднання чинили спротив спробам Саудівської Аравії нав'язати РСАДЗ свій формат безпекової структури об'єднання. Свого апогею такий спротив досяг у грудні 2011 р., коли була оприлюднена Ріядська Декларація, яка проголошувала наміри створити повнокровний союз із уніфікованою воєнною структурою, що було підтримано лише Бахрейном [6]. Катар був протягом багатьох років одним із найбільш небезпечних суперників Саудівської Аравії серед аравійських монархій. Ефективно використовуючи свої колосальні запаси часу, Катар перетворився на провідного постачальника скрапленого газу на світовому ринку. Це створило сприятливі умови для його відносно незалежного зовнішньополітичного курсу. Ефективно використовуючи свої вражаючи фінансові ресурси та телеканал «Аль-Джазіра», Катар перетворився на спонсора «Арабської весни» та такої ії провідної політичної сили, як «Брати-мусульмани». За iï допомогою катарське керівництво намагалось реалізувати свої геополітичні амбіції в регіоні та перетворитися на одного із головних акторів як в арабському світі, так і на Близькому Сході [10].

На цьому грунті Катар увійшов у відкрите зіткнення з аравійськими монархіями, які вбачали саме в цій організації смертельну загрозу свого існування. У березні 2014 р. Саудівська Аравія, Об’єднані Арабські Емірати та Бахрейн відкликали своїх 
послів з Катару. Цю першу дипломатичну кризу було врегульовано через 9 місяців за посередництвом Еміра Кувейту шейха Сабаха Аль-Ахмеда Аль-Джабара. Однак, у 2017 р. ситуація серйозно змінилася. Після приходу до влади у США нового президента Д. Трампа $з$ його відверто антиіранською позицією, почала складатися тісна антиіранська коаліція у складі США, Саудівської Аравії, Об’єднаних Арабських Еміратів та деяких інших арабських країн, а також Ізраїлю. Позиція президента США Д. Трампа, який прямо звинуватив іранський режим у тому, що він є головним спонсором і організатором тероризму на Близькому Сході, фактично розв'язала саудитам та еміратцям руки у їхньому спільному бажанні покінчити із надто самостійною політикою Катару, насамперед у його відносинах з Іраном. Практично ті жорсткі кроки країн-членів «Антитерористичного квартету» щодо Катару означали публічне показове побиття нинішнього катарського керівництва 3 тим, щоб він або кардинально змінив свій зовнішньополітичний, відмовився від своїх амбіцій стосовно якоїсь своєї унікальної ролі в регіоні або поступився місцем новій команді.

Катарська криза продовжується вже другий рік і не має за своєю глибиною, непримиренністю та гостротою аналогів в історії становлення та розвитку РСАДЗ. За цей період відносини між Катаром і чотирма країнами «Антитерористичного квартету» продовжували загострюватися, а розкол між ними лише поглибився [6;5].

Незважаючи на всі зусилля, блокада Катару не тільки не досягла своїх цілей, а навпаки, сприяла формуванню нового альянсу Катар-Туреччина-Іран. Катар значно посилив свою економічну та військово-політичну співпрацю з Туреччиною, яка створила на території Катару свою військову базу. Швидкими темпами розвивається співробітництво Катару з Іраном. Катар повернув до Тегерану свого посла. Торговельний баланс між двома країнами стрімко виріс і досягнув позначки 2 млрд дол. протягом останнього року [5].

Найбільш постраждалою стороною конфлікту виявилась РСАДЗ. Протягом майже чотирьох десятиліть зазначена інтеграційна структура небезпідставно вважалась однією із найбільш успішних не лише на регіональному, а й на міжнародному рівнях. Ї̈̈ глибока криза дала поштовх до початку формування нових інтеграційних альянсів. У грудні 2017 р. під час роботи 38-го саміту РСАДЗ було сформовано новий військовий та торговельний союз між Саудівською Аравією та Об'єднаними Арабськими Еміратами у воєнній, політичній, торговельній і культурній сферах заради інтересів обох країн [11]. Цей новий альянс, утворений у рамках РСАДЗ, імовірно, стає базою для формування нового інтеграційного об'єднання, до якого заплановано входження країн-членів «антитерористичного квартету» та Йорданії. Підтвердженням цих намірів є висування наслідним принцом Саудівської Аравії Мохаммедом бін Салманом нового грандіозного мегапроекту NEOM, який створює необхідні рамкові формати для інтеграції економік Саудівської Аравії, Сгипту та Йорданії. Також дуже показовим є швидка допомога Йорданії з боку Саудівської Аравії, Об'єднаних Арабських Еміратів та Кувейту для подолання економічної кризи, що значною мірою стала наслідком негативного впливу на Йорданію «Арабської весни». Зазначені країни 
надали допомогу в обсязі 2,5 млрд дол. для підтримки курсу йорданського динара та забезпечення політичної стабільності в країні [14].

Нинішні особливості та тенденції розвитку інтеграційних процесів та історичного розвитку арабських країн Затоки важливо належним чином враховувати при опрацюванні зовнішньополітичної та безпекової стратегії Української держави. При цьому Україна має враховувати економічний потенціал країн, що входять до РСАДЗ. Арабські країни Затоки в цілому посідають сьогодні 6-те місце у глобальній економіці за обсягами своєї економіки [1].

По-перше, країни-члени РСАДЗ є послідовними прихильниками територіальної цілісності України і дотримуються позиції щодо необхідності повернення Україні анексованого Криму та частини окупованої території Донецької і Луганської областей. У 2018-2019 рр. важлива країна-член РСАДЗ - Кувейт - буде непостійним членом ради Безпеки ООН, і ця країна виступатиме серйозним союзником у боротьбі із російською агресією, адже майже 30 років тому сам Кувейт пережив фактично таку ж трагедію внаслідок брутальної окупації саддамівським Іраком. Також вкрай важливо, що під час офіційного візиту Президента України П. Порошенка до Кувейту у березні 2018 р. було досягнуто домовленості про координацію зусиль України та Кувейту у раді Безпеки ООН щодо боротьби за відновлення їі територіальної цілісності [14]. Також під час свого візиту Президент України П. Порошенко попросив Еміра Кувейту, керівництво цієї країни допомогти Україні стати членом на правах спостерігача такої впливової організації, як Організація ісламської співпраці. Такий крок значно поглибить рівень співпраці України з ісламським світом, тим більше, що такі впливові члени цієї організації, як Саудівська Аравія, Кувейт та Катар - члени РСАД3, підтверджують свою готовність всіляко допомагати Україні у забезпеченні законних прав кримськотатарського народу. Перебуваючи в Організації ісламської співпраці навіть на правах спостерігача, Україна отримає серйозні преференції в отриманні інвестицій з боку провідних арабських та інших мусульманських країн.

Не менш важливим є налагодження плідної співпраці України з арабськими країнами Затоки в енергетичній сфері. Особливо велику надію Україна покладає на співпрацю з Катаром у забезпеченні енергетичної безпеки нашої країни. Катар має величезні поклади газу, він постачає на світовий енергетичний ринок майже третину всіх продажів скрапленого газу. Під час робочого візиту Президента України до Катару у березні 2018 р. пророблялось питання щодо надходження до України катарського скрапленого газу танкерами через термінал у Польщі [17]. Така співпраця з Катаром надасть нашій країні велику допомогу у нейтралізації спроб нинішньої російської влади створити серйозну загрозу енергетичній безпеці України.

Також арабські країни Затоки, особливо такі, як Саудівська Аравія, Об'єднані Арабські Емірати, Катар та Кувейт, мають колосальні інвестиційні можливості, і у цьому контексті співпраця України з цими країнами в інвестиційній сфері має серйозні перспективи [17]. 
Щодо наявних проблем у взаємовідносинах між країнами-членами РСАДЗ, особливо стосовно шляхів подолання катарської кризи, Україна вважає, що немає альтернативи розв'язання регіональних конфліктних ситуацій шляхом мирних переговорів.

3'ясовано, що перспективними напрямами подальшого опрацювання теми $\epsilon$ виявлення потенційних можливостей формування такого нового утворення, як Близькосхідний стратегічний альянс (MESA), перспективи збереження та шляхів трансформації Ради співробітництва арабських держав Затоки, місце нинішніх змін у формах співробітництва країн Затоки у загальносвітових історичних транзитивних процесах.

\title{
Summary
}

The article is an attempt to analyse historical roots of creation of the contemporary integration architecture in the Gulf region as well as to disclose principal tendencies and particularities of development the integration processes in the above-mentioned region after "Arab Spring». The author also researches influence on complication of integration processes in the organisation of the Gulf Cooperation Council (GCC) of following factors: significant sharpening of Iran-Saudi confrontation, Middle East policy of the new USA president Donald Trump, Qatar crisis etc.

The article is an attempt to research the latest attempts of Saudi Arabia together United Emirates to formulate a new centre of integration gravity of loyal to them Arab states, first of allEgypt and Jordan with the help of the following projects like a new military, political and economic union between Saudi Arabia and UAE as well as such project as NEOM.

The author also formulates main conclusions that are to be taken into consideration while evaluating the contemporary condition of integration processes and geopolitical balance in the Gulf region for the implementation of strategic tasks of Ukraine in the whole Middle East and the Gulf region in particular.

Key words: integration processes, The Gulf, Gulf Cooperation Council, Qatari Crisis.

\begin{abstract}
Аннотация
Проанализированы исторические истоки формирования современной интеграционной архитектуры в таком ключевом регионе Ближнего Востока, как Залив; определены главные тенденции и особенности развития интеграционных прочессов в указанном пространстве после революций «Арабской весны». Выявлены основные факторы повышения роли аравийских монархий в арабском мире на протяжении указанного времени.

Исследовано влияние на усложнение прочессов интеграџии в рамках такого объединения, как Совет сотрудничества арабских государств Залива (ССАГЗ) таких факторов, как заметное обострение саудовско-иранского противостояния, ближневосточная политика нового президента США Д. Трампа, катарский кризис и другие.

Рассматриваются последние попытки Саудовской Аравии совместно с Объединенными Арабскими Эмиратами сформировать новый центр интеграчионного притяжения лояльных к ним арабских государств, прежде всего Египта и Иордании, через такие проекты, как новый военно-политический и экономический союз между Саудовской Аравией и ОАЭ, а также проект NEOM.

Сформулированы основные выводы для учета нынешнего состояния интеграционных прочессов и геополитического баланса в регионе Залива на реализацию стратегических задач Украины на Ближнем Востоке в иелом и в регионе Залива в частности.

Ключевые слова: интеграционные процессы, Ближний Восток, Залив, Совет сотрудничества арабских государств Залива, катарский кризис.
\end{abstract}




\section{ДЖЕРЕЛА ТА ЛІТЕРАТУРА}

1. Al-Baqmi. Saudi Deputy Crown Prince: Gulf States to Become World's 6th Largest Economy. November 11, 2016. URL: https://eng-archive.aawsat.com/shuja-baqmi/ news-middle-east/saudi-arabia/saudi-deputy-crown-prince-gulf-states-become-worlds6th-largest-economy

2. Althaydi M. Jordan between friends and enemies. 14 June, 2018. URL: https://english.alarabiya.net/en/views/news/middle-east/2018/06/14/Jordan-between-friends-andenemies.html

3. Chulov M. I will return Saudi Arabia to moderate Islam, says crown prince. The Guardian. 24 October, 2017. URL: https://www.theguardian.com/world/2017/oct/24/i-willreturn-saudi-arabia-moderate-islam-crown-prince

4. Koch Ch. Success and Shortcomings of GCC Economic "Vision" Documents. 31 May, 2017. URL: http://www.arabdevelopmentportal.com/blog/success-and-shortcomingsgcc-economic-"vision"-documents

5. Kabalan M. How the blockade on Qatar failed. 4 Jun, 2018 URL: https://www.aljazeera.com/indepth/opinion/blockade-qatar-failed-180602145011055.html

6. Miller R. The Gulf crisis: How it all started. 1 June, 2018 URL: https://www.aljazeera.com/indepth/opinion/gulf-crisis-started-180531140250121.html

7. Dr. Omar Al Hassan The GCC's Formation: The Official Version. Aljazeera Centre for Studies. 30 March, 2015. URL: http://studies.aljazeera.net/en/dossiers/2015/03/2015 33011258831763.html

8. The new Saudis Chaos in the Middle East casts Saudi Arabia as the Arab world's leader. But it must reform faster. The Economist. May 23, 2015. URL: https://media.economist.com/news/leaders/21651821-chaos-middle-east-casts-saudi-arabia-arab-worldsleader-it-must-reform

9. Trager E. The Muslim Brotherhood Is the Root of the Qatar Crisis. The Atlantic. July 2, 2017. URL: https://www.washingtoninstitute.org/policy-analysis/view/the-muslim-brotherhood-is-the-root-of-the-qatar-crisis

10. Wahba M. M. The Role of the Gulf Arab States in a Transforming Middle East. September 29, 2017. URL: http://www.agsiw.org/role-gulf-arab-states-transforming-middle-east/

11. UAE and Saudis form new partnership separate from GCC. 5 December, 2017. URL: https://www.aljazeera.com/news/2017/12/uae-saudi-arabia-form-political-partnership171205075923016.html

12. Doha's attitude keeps it isolated from neighbors. The Arab Weekly. 03 June, 2018. URL: https://thearabweekly.com/dohas-attitude-keeps-it-isolated-neighbours

13. Катар готовий надати Україні скраплений газ - Глава держави. 20 березня 2018 р. URL: http://www.president.gov.ua/news/katar-gotovij-nadati-ukrayini-skraplenij-gazglava-derzhavi-46522

14. Президент України провів зустріч з Віце-прем'єр-міністром, Міністром закордонних справ Кувейту. 18 березня 2018 p. URL: http://www.president.gov.ua/news/ prezident-ukrayini-proviv-zustrich-z-vice-premyer-ministrom-46466 
15. Субх М. А. Трансформаційні процеси в країнах Ради співробітництва арабських держав Затоки в умовах глобалізації (2001-2010рр.) : автореф. дис. ... канд. іст. наук. Київ, 2015. 26 с.

16. Швед В. О. «Арабська весна» у контексті сучасного трансформаційного процесу на Близькому і Середньому Сході. Проблеми всесвітньої історії. 2016. № 1. С. 109-122.

17. Це потужний поштовх, який значно активізує співпрацю України з країнами Затоки - Президент про переговори у Катарі. 20 березня, 2018 p. URL: http://www.president.gov.ua/news/ce-potuzhnij-poshtovh-yakij-znachno-aktivizuye-spivpracyu-uk-46526

\section{References}

1. Al-Baqmi. Saudi Deputy Crown Prince: Gulf States to Become World's 6th Largest Economy. November 11, 2016. URL: https://eng-archive.aawsat.com/shuja-baqmi/ news-middle-east/saudi-arabia/saudi-deputy-crown-prince-gulf-states-become-worlds6th-largest-economy

2. Althaydi, M. Jordan between friends and enemies. 14 June, 2018. URL: https://english.alarabiya.net/en/views/news/middle-east/2018/06/14/Jordan-between-friends-andenemies.html

3. Chulov, M. I will return Saudi Arabia to moderate Islam, says crown prince. The Guardian. 24 October, 2017. URL: https://www.theguardian.com/world/2017/oct/24/iwill-return-saudi-arabia-moderate-islam-crown-prince

4. Koch, Ch. Success and Shortcomings of GCC Economic "Vision" Documents. 31 May, 2017. URL: http://www.arabdevelopmentportal.com/blog/success-and-shortcomingsgcc-economic-"vision"-documents

5. Kabalan, M. How the blockade on Qatar failed. 4 Jun, 2018 URL: https://www.aljazeera.com/indepth/opinion/blockade-qatar-failed-180602145011055.html

6. Miller, R. The Gulf crisis: How it all started. 1 June, 2018 URL: https://www.aljazeera.com/indepth/opinion/gulf-crisis-started-180531140250121.html

7. Dr. Omar Al Hassan The GCC's Formation: The Official Version. Aljazeera Centre for Studies. 30 March, 2015. URL: http://studies.aljazeera.net/en/dossiers/2015/03/2015 33011258831763.html

8. The new Saudis Chaos in the Middle East casts Saudi Arabia as the Arab world's leader. But it must reform faster. The Economist. May 23, 2015. URL: https://media.economist.com/news/leaders/21651821-chaos-middle-east-casts-saudi-arabia-arab-worldsleader-it-must-reform

9. Trager, E. The Muslim Brotherhood Is the Root of the Qatar Crisis. The Atlantic. July 2, 2017. URL: https://www.washingtoninstitute.org/policy-analysis/view/the-muslimbrotherhood-is-the-root-of-the-qatar-crisis

10. Wahba, M. M. The Role of the Gulf Arab States in a Transforming Middle East. September 29, 2017. URL: http://www.agsiw.org/role-gulf-arab-states-transforming-middle-east/ 
11. UAE and Saudis form new partnership separate from GCC. 5 December, 2017. URL: https://www.aljazeera.com/news/2017/12/uae-saudi-arabia-form-political-partnership171205075923016.html

12. Doha's attitude keeps it isolated from neighbors. The Arab Weekly. 03 June, 2018. URL: https://thearabweekly.com/dohas-attitude-keeps-it-isolated-neighbours

13. Katar gotovij nadati Ukrayini skraplenij gaz - glava derzhavi. 20 bereznya 2018 [Katar is ready to deliver Ukraine liquefied gas - Head of State]. URL: http://www.president.gov.ua/news/katar-gotovij-nadati-ukrayini-skraplenij-gaz-glava-derzhavi-46522

14. President Ukrayini proviv zustrich z vice-premierom, ministrom zakordonnyh sprav Kuveyta, 2018, 18 bereznya [The President of Ukraine conducted meeting with the vice-premier-minister, minister of foreign affairs of Kuwait]. URL: http://www.president.gov.ua/news/prezident-ukrayini-proviv-zustrich-z-vice-premyer-ministrom-46466

15. Subh, M. Transfomatsiyni procesi v krainah Rady spivrobitnitstva arabskyh derzhav Zatoky v procesah globalizacii (2001-2010 rr.) [Transformations processes in Arab Gulf States (2001-2010)]. Abstract of Ph. D. thesis. Kyiv, 2015.

16. Shved, V. O. «Arabska vesna» v konteksti suchasnyh transformactiynyh procesiv na Blizkomy i Serednyomy Shodi [ «Arab spring» in the Context of Contemporary Transformations Process in the Near and Middle East]. Problemi vsesvitnyoi istorii: naukovyi zhurnal, 2016, 1, 109-122.

17. Ce potuzniy poshtovh yakiy znachno aktivizuye spivpratcu Ukrayini z krainami Zatoki, 20 bereznya 2018 [This is a strong impuls which significantly actives the cooperation of Ukraine with Gulf States, March 20, 2018]. URL: http://www.president.gov.ua/news/ce-potuzhnij-poshtovh-yakij-znachno-aktivizuye-spivpracyu-uk-46526.

УДК $340.15: 342.7$

\section{ДОТРИМАННЯ ПРАВ ЛЮДИНИ В ІРАНІ: ЕВОЛЮЦІЯ ПРОБЛЕМИ ВІД МАХМУДА АХМАДІНЕЖАДА ДО ХАСАНА РУХАНІ}

\section{Пилипенко Вікторія}

Основним завданням автора є спроба показати особливість формування державної політики Ісламської Республіки Іран за президентства Махмуда Ахмадінежада й Хасана Рухані щзодо впровадження та дотримання Деклараџї прав людини і громадянина в усіх сферах суспільного та політичного життя країни.

В основі методологічної бази дослідження покладено загальнонаукові приниипи аналізу та синтезу, метод критичного аналізу джерел та історико-генетичний метод, щьо дали можливість прослідкувати динаміку розвитку ситуації в Ірані навколо дотримання прав людини. У пропонованій статті дослідником було використано системний підхід, завдяки якому вдалося виявити складові елементи побудови іранської державної політики щуодо опозиційних сил, правозахисників та незалежних журналістів. 